\title{
Deciphering Chinese Capital Markets: Current Scenario, Challenges and Potential
}

\author{
Enakshi Jha*
}

\section{Abstract}

China undoubtedly has had always the world's attention, ranging from the issues of governmental and economic control to its increasing rates of production. Termed to be the world's production capital, this oriental country has an ever evolving capital markets structure that is often categorized as merely governmental control. The past few years has essentially witnessed a metamorphosis of this myth as Chinese capital markets are undergoing a change in terms of both their structure and the substantive law governing the same. China has opened its gates to foreign investors and has endeavoured to attain a more transparent procedure to attract investment in the country by permitting their entry the capital markets structure. However, this privatization and entry of foreign players in the Chinese capital markets is dampened by the vigorous control of the Chinese government, thereby leading to questions regarding the legitimacy of an open capital market structure. Further, China's association with Hong Kong through its stock exchange has gained relevance in the past few years, drawing the attention of global investors. This paper attempts to analyse the past, the present and the future potential of one of Asia's leading economies as it could hold the key to transformation of global economics and trade. The researcher has adopted a comprehensive method by focusing primarily on the securities market in China,

* Third Year, BA, LLB (Hons.), National Academy of Legal Studies and Research (NALSAR), Hyderabad; jhaenakshi@gmail.com. 
along with drawing light on the status quo and the challenges in other tools of capital markets like the bonds and sovereign funds. This method of analysis leads the researcher to promulgate the view that China has taken initiative to open its capital markets structure and is committed to become a global player but remains reticent due to the massive governmental control at each level of regulation in the capital markets structure.

Keywords: Capital Market Structure, Chinese Security Regulatory Commission, Economic Growth, Governmental Regulation, Hong Kong Stock Connect.

\section{Introduction}

In an interconnected world characterized by symbiotic economic activities, capital markets form the backbone of transactions. While 'capital markets' is an umbrella term for an assortment of economic markets like equity and bond markets they operate hand in hand to enable financial transactions. In the recent times, China is a significant player in the world of capital markets due to not only its possibilities that are becoming available to other international players but also due to the very size of its economy.

However, it is essential to recognize that the Chinese capital markets are not as open as other international capital markets such as the United States of America. The barricades of government regulation and approval limit the scope of entry into Chinese capital markets. ${ }^{1}$ On the other hand, China's entry into the World Trade Organization has made its internal securities market more attractive to investors internationally. ${ }^{2}$

Presently, it is possible for foreign investors to hold Chinese securities subject to approval. This poses a spectrum of difficulties in capital transactions, which this paper attempts to analyse. Chinese government structures and their control of capital markets

${ }^{1}$ Dong Anshen and Han Liyu, How Law Reform Enhances Trading on the Chinese Capital Market, 10 UNI. L. REV. 225, 226-27 (2005).

2 Yuwa Wei, Volatility of China's Securities Markets and Corporate Governance, 29(2) SUFFOLK TRANSNAT'L L. REV. 207 (2006). 
are often criticized for allowing limited interaction with foreign players. This often leads to problems of volatility that makes it difficult to predict the future of Chinese capital markets. ${ }^{3}$ This paper therefore seeks to outline the challenges faced by the Chinese capital markets both internally in China and the obstacles international investors face in transacting with China.

While recognizing the limitations of Chinese capital markets, it is essential to examine China's economic power both in Asia and internationally. In 1970 China attempted an economic reform aimed at replacing the existing state owned and controlled economy to a market players' economy characterized by multiple players. This led to the birth of China's leading national security exchanges, the Shanghai and the Shenzhen Stock Exchange. ${ }^{4}$

These exchanges today play an active role and have the potential of becoming larger to enable greater international interaction. China as a nation is known for its saving pattern and capital markets attempt to channel such savings to pump the financial system, while regulating such transactions with the formation of national stock exchanges. The population and saving pattern in China therefore become incentives for growth of capital markets in China. ${ }^{5}$

This paper also attempts to exemplify this potential and analyse its impact on capital markets. Part I of this paper elucidates the current situation and history of capital markets in China. The author has primarily focused upon the securities market to narrow the scope of research. Part II throws light on the challenges Chinese

${ }^{3}$ Dehuan Jin, A Study of Volatility of the ChINESE SECURITIES MARKET AND CONTROL 12-13 (Publishing House of Shanghai University of Finance and Economy, 2003).

4 Serena Y. Shi, Comment Dragons' House of Cards: Perils of Investing in Variable Interest Entities domiciled in the People's Republic of China and Listed in the United States, 37 FORDHAM INT'L L.J. 1265, 1265-66 (2014).

${ }^{5}$ Financial Sector Assessment, China: Financial Sector Assessment Program, (Nov.,

http:/ / www.worldbank.org/content/dam/Worldbank/document/WBChinas-Financial-Sector-Assessment-Report.pdf, (last visited on Mar. 20, 2015). 
capital markets face and the last part analyses the future possibilities for Chinese capital markets.

\section{Chinese Capital Markets: Current Scenario}

\section{Impact of the Trend of Savings in China}

Before, the economic system in China changed in the 1970s; the savings of the people in China were merely deposited in state banks. ${ }^{6}$ However, with the emergence of stock exchanges such savings now form a capital resource, which amounts to almost 40 percent of China's Gross Domestic Product. 7 Secondly, the emergence of national stock markets has introduced a system of procedures and regulations that need to be followed to be a player in the Chinese capital markets.

Previously, this was absent, leaving state run enterprises and companies without any checks and balance system. Together these factors have led to a more efficient capital markets regime as compared to the past. Unlike the common myth surrounding Chinese corporations, it is essential to realize that companies in China are encouraged to be listed and to form a part of the local capital markets structure as this allows greater participation and enables the government to curb the menace of insider trading that has long plagued Chinese corporations. ${ }^{8}$ In the lack of a clear corporate governance code, this encourages private companies to be listed as well, thereby aiding competition and enhancing market transparency. However, corporate governance and capital markets share a directly proportionate relationship that poses an obstacle currently to China's capital markets and shall be discussed in greater detail in the latter sections of this paper. ${ }^{9}$

${ }^{6}$ Solomon M. Karmel, Emerging Securities Markets in China: Capitalism with Chinese Characteristics, CQY, 1105, 1105-20 (1994).

7 John H Makin, Does China save and Invest Too Much, 26(2) CATO J. 307, 316-17 (2006).

${ }^{8}$ Dong, supra note 1 at 225.

9 Donald C. Clarke, Law without Order in Chinese Corporate Governance Institutions, 30 NW. J. INT'L L. \& BUS. 131 (2010). 


\section{Understanding the Securities Market in China}

Until 1992 the Peoples' Bank of China regulated the Chinese securities market. In 1992, this changed with the formation of a regulatory framework. The economic atmosphere and the threat of unrest led to a pressing need to form a regulatory body that could unify the practices in the securities market in China. The first Securities law was hence passed in 1998 to provide standard practices and attain investor protection. ${ }^{10}$ The 214 Articles of this statute regulate and unify the issuance and transfer of shares while specifying liabilities for violating any provisions of the statute. It further recognizes that company or administrative law would govern any lacunae in securities law. ${ }^{11}$

To appreciate the structuring of securities markets in China, it is paramount to discuss the types of shares and shareholder protection. Chinese law endorses equal shareholder protection for common classes of shares ${ }^{12}$. However shares are fragmented in the capital market structure as they depend on who holds the shares and whether they are listed or not. ${ }^{13}$ Shares are primarily divided into tradable and non-tradable categories. For non-tradable shares, exchange is possible only in private transactions and with prior government approval. ${ }^{14}$ Tradable shares on the other hand can be traded both in the national and the international stock markets. Two third of non-tradable shares lie in the hands of governmental authority in China leading to investors in listed companies to

10 Daniel M Anderson, Taking Stock in China: Company Disclosure and Information in China's Stock Markets, 88 GEO. L. J. 1919 (2000).

${ }^{11} \mathrm{Id}$.

12 Shen, Han, A Comparative Study of Insider Trading Regulation Enforcement in the U.S. and China, 9(1) J. BUS. \& SEC. L. 42 (2008).

${ }^{13}$ Filip Moerman and Niping Wu, China's Quest for Sound Capital Markets, 24 INT'L FIN. L. REV. 25-26 (2005).

14 Yeung, Horace W. H., Non-Tradable Share Reform in China: Marching Towards the Berle and Means Corporation? CLPE Research Paper No. 48/2009 (Nov. 30, 2009). 
worry about the possibility of them flooding the market. ${ }^{15}$ Nontradable shares are also sold privately at discounted rates as compared to the rates at the national stock exchange. Further, similar shares are traded at different prices in China and abroad catalyzing the problems of a super fragmented share structure. ${ }^{16}$

\section{Dichotomy in the Division of Shares}

Shares can be further divided into type A and type B shares. Type A shares are those owned by the domestic investors and are controlled by the local currency and Type B shares are owned by foreigners and while their face value is calculated in Chinese Yuan, trading takes place by means of foreign currency. ${ }^{17}$

Type A shares are further divided into three categories that are owned by the state or by legal persons or public individual shares which can be traded on national stock exchanges freely. State shares and legal persons however face restrictions and hence are known as non-tradable shares. ${ }^{18}$ This classification of shares and the lack of uniformity of the applicable rules have led to the slowing down in the growth of the Chinese capital markets and has affected capital rising. To resolve the same, the government has allowed type B shares to be made available to local investors in the foreign currency and is slowly allowing foreigners to buy type A shares thereby limiting the distinction between type A and B shares. ${ }^{19}$

Unfortunately, this has posed a problem with respect to tradable and non tradable shares as non tradable shares came into existence

15 Annette Kleinbrod, The Chinese Capital Market Performance, PARAMETERS AND FURTHER EVOLUTION AND IMPLICATIONS FOR DEVELOPMENT 84-85 (Wiesbaden: Deutscher Universitaits-Verlag, 2008).

16 Hui Huang, The New Takeover Regulation in China: Evolution and Enhancement, 42(1) THE INT'L LAWYER 153-54 (2008).

${ }^{17}$ Hui Huang, China's Takeover Law: A Comparative Analysis and Proposals for Reform, 30 DEL. J. CORP. L. 148-53 (2005).

${ }^{18}$ ANNETTTE, supra note 12 at 85-87.

19 Woody $\mathrm{Wu}$ and Hua Zhang, Shareholding Structure and Corporate Performance of Partially Privatized Firms: Evidence from Listed Chinese Companies, 8 PAC BASIN FINANCE J. 587-93 (2000). 
to prevent the sale of State owned enterprises to private players and this poses a great obstacle to China's capital markets as they are attempting to boost the same. ${ }^{20}$ Hence, in 2005, the government released 'Guquan Fenzhi Gaige' a structural reform to allow converting non-tradable shares to tradable shares via negotiations between public shareholders who have tradable shares and the state that has non-tradable shares. This has been seen as a success and the stock markets rise is proof of the same. ${ }^{21}$

\section{Regulators in the Chinese Capital Market Structure}

Lastly, to appreciate the current position of the Chinese capital markets, the history and evolution of regulatory authorities has to be examined. In 1993 China saw the formation of the Commission on Restructuring of the Economic System (CRES) in the absence of a company law statute. ${ }^{22}$ This commission released a sub statutory regulation that assimilated all fiduciary duties and jurisprudence of Hong Kong into the Chinese law, for Chinese firms that were listed or issuing stock in Hong Kong while being domiciled in China. ${ }^{23}$ The emergence of China's corporate law statute in 1994 very conveniently absorbed the same and reinstated that corporate fiduciary duties and governance norms would be applied to all China domiciled listed firms who are operating overseas and issuing stock, to include Hong Kong within its regulatory ambit. ${ }^{24}$

${ }^{20}$ Hui, supra note 16 at 153.

${ }^{21}$ GuAnghuA Yu, The Development Of Chinese LeGAl SySteM: CHANGE AND CHALLENGES 10.3 (Routledge, 2010 ).

22 Nicholas C. Howson, China's Company Law: One Step Forward, Two Steps Back--A Modest Complaint, 11 COLUM. J. ASIAN L. 127 (1997).

${ }^{23}$ Nicholas Calcina Howson, "Quack Corporate Governance" As Traditional Chinese Medicine-The Securities Regulation Cannibalization of China's Corporate Law and a State Regulator's Battle Against Party State Political Economic Power, 37 SEATTLE U. L. REV. 667-68 (2013-2014).

24 Nicholas C. Howson, The Doctrine That Dared Not Speak Its NameAnglo-American Fiduciary Duties in China's 2005 Company Law and Case Law Intimations of Prior Convergence, in TRANSFORMING CORPORATE GOVERNANCE IN ASIA BY HANDA KIM AND CJ MILHAPUT, 193-94 (London: Routledge, 2008). 
Secondly, unlike capital market regulators across the world, China has internal regulators who are often supporters of the government. ${ }^{25}$ Corporate governance and securities regulations lose borders and are often redrafted in the form of substantive norms or procedural rules. This not only questions the ability of checks and balances in the Chinese capital market, but also violates the very institution of law. ${ }^{26}$ The reality is much murkier with instances in which it has been argued that breaches of legal duties imposed on listed companies must be tried by the norms of the securities regulator instead of applying China's corporate law. This reality in China often leaves capital markets vulnerable due to the lacunae in the applicable law. Parties to such conflicts are often forced to discontinue litigation due to this lack of clarity, thereby limiting stability in the capital markets. ${ }^{27}$ The sections below study the key players and markets that come together to form the capital market structure in China.

\section{Role of the Chinese Security Regulatory Commission (CSRC)}

\section{Checks and Balances in the Financial System}

Despite having laws regarding capital markets, especially securities law, China faces an efficiency problem due to the different regulatory authorities controlled by the government trying to implement securities regulations. ${ }^{28}$ This is aptly seen in the securities regulator in China, the Chinese Security Regulatory Commission (CSRC)'s invasion of Chinese corporate law. While the corporate reforms in China starting from 1994 attempted to give the judiciary greater power in filling in the gaps in substantive law and enforcing the standards of regulation, China's security regulators have ensured the opposite. ${ }^{29}$

${ }^{25}$ Chenxia Shi, Competition in China's Securities Market: Reform of Current Regulatory System, 3 Loy. U. CHI. INT'L L. REV. 213 (2006).

${ }^{26}$ Howson, supra note 23 at 667.

27 Id.

28 Shi, supra note 25 at 213.

${ }^{29}$ Nicholas C. Howson, Corporate Law in the Shanghai People's Courts 1992- 
The CSRC has intruded into the sphere of corporate governance, by enforcing corporate governance norms, as the regulating authority of capital markets. This 'self-enforcing' of corporate laws by the CSRC and Chinese bureaucrats has therefore limited Chinese capital markets from becoming independent and metamorphosing towards privatization. 30

\section{Problems with State intervention in the CSRC: Corporatization without Privatization}

Further, the CSRC mandates the submission of certain documents that is to be disclosed in order to enable the investors to make informed choices. ${ }^{31}$ Listing agreements, shareholders' meeting, resolutions and financial reports along with their release prior to the listing of a public company has been mandated. Securities law is hand in hand with the company law provisions regarding the same. ${ }^{32}$ While this may be in contradiction to the previous section, it is essential to note that the presence of company law statutes and the securities law existing together often leads to less investor protection in the Chinese capital markets. Company law mandates the approval of governmental authority for the listing of a company giving the state greater control over which companies are allowed to issue stocks. ${ }^{33}$ The CSRC then establishes a committee which studies all the material provided and votes on whether the company should be listed or not. This system only cements state control in publicly traded shares. ${ }^{34}$ Further the existence of such disclosure requirements fails in China as authorities have the power to block issuance of certain shares giving the investor

2008: Judicial Autonomy in a Contemporary Authoritarian State, 5 E. ASIA L. REV. 303, 304-05 (2010).

30 Howson, supra note 23 at 668.

${ }^{31} \mathrm{Id}$.

32 Chen Daisong, Legal Developments in China's Securities Market During three decades of Reform And Opening-Up 1, 6 (Asian Law Institute and National University of Singapore ,Working Paper No. 005, 2009).

33 Daniel M. Anderson, Taking stock in China: Company disclosure and information in China's stock markets, 88 GEO. L.J. 1919 (2000).

${ }^{34}$ Howson, supra note 23 at 668. 
limited power to challenge or analyse the grounds of the same. ${ }^{35}$ However, to ease this unpleasant scenario the securities law attempts to make the grounds of such decision making public. ${ }^{36}$ Unfortunately, this does not force the CSRC from making its new regulations public, leaving investors in the same plight.

Hence, China's dilemma of 'corporatization without privatization' continues with the state operating enterprises directly or controlling them via agencies like the CSRC, limiting the growth opportunities for individual shareholders and the capital markets in China 37. This takes away China's glorious attempts of corporatization of capital markets, as the state continues to focus on maximization of wealth for all shareholders (minority shareholders), often converging with the Chinese state's control and exploitation of minority interests. ${ }^{38}$

\section{Foreign Players in the Chinese Markets}

\section{Non Uniform Treatment of Investors in China}

China regulates the entry of foreign players and its capital management policies prevent citizens from investing their savings in certain asset categories that are more attractive. This is coupled with the low number of offerings in the Chinese securities market leading to inflated pricing of shares. ${ }^{39}$ Together, these factors leave China vulnerable to a financial crisis as the fear of the Chinese financial bubble bursting on account of any change in the over protected Chinese capital markets exists. ${ }^{40}$ Chinese securities

35 Wong Nancy, Easing down the Merit-Disclosure Continuum: A Case Study of Malaysia and Taiwan, 28(1) LAW POLICY INT'L BUS. (1996).

36 Yuwa Wei, The Development of the Securities Market and Regulation in China, 27 LOY. L.A. INT'L \& COMP. L. REV. 479 (2005).

${ }^{37}$ Howson, supra note 23 at 667.

38 Id. at 668 .

39 Phillip Barber, Bull in the China Market: The gap between investor expectations and auditor liability for Chinese Financial Statement Frauds, 24 DUKE J. COMP. \& INT'L L. 349-50 (2014).

40 Lee Ming Hau, Encouraging Foreign Participation and Investment in Chinese Securities Markets, 23, SING. L. REV. 125-26 (2003). 
markets are often recognized by the existing 'nationality principle' which distinguishes between Chinese nationals and foreign investors. Article 138 of the Securities Law provides for the need to be a Chinese entity or person in order to open a trade account in China. ${ }^{41}$ Another weakness of this principle lies in the classification of shares, which is based on corporate ownership and the consequent issuances of shares. This is quite contrary to western economies where stocks are classified only on the basis of expected dividends. ${ }^{42}$

\section{The Menace of Share Classification}

Type A shares that are controlled by the Renminbi can be traded only by Chinese nationals and Qualified Foreign Institutional Investors (QFIIs). Type A shares dominate the equity market in China causing the importance and demand for type B shares to dwindle. ${ }^{43}$ Hence this situation has contributed to the merging of the two types of shares as type A shares have gained importance at the cost of type B shares fading away. Type A shares can be listed on the Hong Kong stock exchange along with type $\mathrm{H}$ shares making them popular. ${ }^{4}$

In 2006, China also allowed Qualified Domestic Institutional Investors (QDII) to invest abroad.45 This has currently helped China

41 ORGANISATION OF ECONOMIC AND COOPERATION AND DEVELOPMENT, CORPORATE GOVERNANCE OF LISTED COMPANIES IN CHINA: SElFASSESSMENT BY THE CHINA SECURITIES REGUlATORY COMMISSION (O.E.C.D. Publishing, 2011) available at, http://dx.doi.org/10.1787/9789264119208en (last visited on Sep. 20, 2015).

$42 \mathrm{Id}$.

43 Huang (Robin) Hui, China's New Regulation on Foreign MEA: Green Light or Red Flag?,13(2) U.N.S.W. LAW J. 30-36 (2007).

${ }^{44} \mathrm{KPMG}$, China's Capital Markets: The Changing Landscape, KPMG: CUTTING THROUGH COMPLEXITY, available

https://www.kpmg.com/cn/en/IssuesAndInsights/ArticlesPublications /Documents/China-Capital-Markets-FTSE-201106.pdf (last visited on Mar. 18, 2015).

45 Daniel H. Rosen and Zhi Wang, The Implications of China-Taiwan Economic Liberalization, PETERSON INSTITUTE FOR INTERNATIONAL 
deal with balancing demand and supply in the foreign exchange market and allowed Chinese intuitional investors to explore a wider variety of products to invest in, helping them diversify their investments. ${ }^{46}$

\section{Role of Enterprise Managers in China}

In the present situation in China, enterprise managers are gaining importance. In an environment of government regulation both directly and indirectly, enterprise managers in China sell securities of other companies to raise capital. Stock corporations are formed within the caps placed by the government and often the gates of corruption in China enable such managers to control such companies and attain membership to the boards of newly formed corporations. ${ }^{47}$ Securities laws in China do not ban government employees or members of the Communist Party from attaining such positions. This leads to a vicious nexus between managers and the government leading to greater instances of corruption and insider trading. ${ }^{48}$

While this paints a gloomy picture for the future of Chinese capital markets, private investors and employees in China find a ray of hope in the newly formed disclosure rules and annual reports that have to be published by all listed companies. This enables shareholder protection in China and is an attempt to move towards transparency in capital markets. ${ }^{49}$ However, it is crucial to remember that in the current scenario, private investors remain vulnerable in a system, which is both controlled by the

ECONOMICS, available at: http://www.gbv.de/dms/zbw/638302579.pdf (last visited on Mar. 18, 2015).

${ }^{46}$ Yong ZHIEN, CHINA's CAPITAL MARKeT 160-61 (Woodhead Publishing Ltd., 2013).

47 Jing Leng, Interaction between Domestic and Overseas Capital Markets and Corporate Governance of Chinese Listed Companies, in CORPORATE GOVERNANCE POST-ENRON - COMPARATIVE AND INTERNATIONAL PERSPECTIVES (United Kingdom, 2006).

${ }^{48}$ Solomon, supra note 6 .

49 Douglas Cumming, DeVeloping China's Capital Market: EXPERIENCES AND CHALLENGES 148-49 (Palgrave Macmillan, 2013). 
government, and the government is also the largest investor in the capital markets.

Grievance redressal is limited and laws are constantly changing leaving individual investors with limited rights. The very idea of Mao's 'Democratic centralization' fails in this context. ${ }^{50}$ Private investors who are often uninformed and do not have access to full disclosure either by companies or by free press like in most other jurisdictions make decisions on rumours or patterns of price listings, leaving them vulnerable to market volatility.

This in turn impacts investment into securities market in China but does not incentivize the government to enact strict disclosure norms or educate private investors as 75 percent of listed companies are held by the state, making private investors an unfortunate minority in Chinese capital markets. This has also scared foreign investment from entering the Chinese capital market. 51

\section{Role of Sovereign Funds in Chinese Capital Markets}

Sovereign wealth funds in China also contribute to the capital markets structure. The National Social Security Fund (NSSF) and the China Investment Corporation (CIC) are the biggest players in this sector. ${ }^{52}$ NSSF was set up to help China's future pension provision problem and continues to grow today. This has led to the NSSF emerging as the largest institutional investor in the pension sector in mainland China. ${ }^{53}$

CIC on the other hand was formed for diversification of reserves and to multiply returns by investing in long term projects. Since it

50 Solomon, supra note 6.

51 Id.

52 Chengxi Yao, Market Structure Of The Chinese Equity Markets, 19 FORDHAM J. CORP. \& FIN. L.109 (2013).

${ }^{53}$ KPMG., supra note 32. 
is a governmental organization it has high stakes in national banks and other financial institutions in the name of the government. ${ }^{54}$

\section{The Role of Bonds in China}

The bond market in China is primarily composed of government bonds, which have influenced both financial sector reforms and China's macroeconomic policies. However, their role has remained limited in the Chinese capital markets, as they have failed to meet the demand created by the economic growth. ${ }^{55}$ Further, bond composition is uneven as 80 percent of the bonds are governmental bonds. Credit bonds and corporate bonds do not play a major role in Chinese capital markets and the problem of cross border transactions involving bonds remains murky in the absence of a clear regulatory framework. ${ }^{56}$ However, things have improved with China extending the currency denomination of these bonds instead of the previously limited bonds released only in Reminibi. The CSRC has also introduced corporate bonds into the market in 2007 to enable diversification of the bonds market. 57

\section{Challenges Faced by Capital Markets in China}

\section{Policy versus Implementation}

The success of securities markets in China lies not only on the policies but also in their implementation. The policies in China impact not only the internal capital markets but also international competition. Poor corporate governance and misconduct on the

54 US-China Economic and Security Review Commission, China Investment Corporation: Recent Developments in Performance, Strategy, and Governance, (Jun., 2013),

http:/ / uschinareport.com/wp-content/uploads/2013/06/ChinaInvestment-Corporation_Staff-Report.pdf.

55 LARDY, N.R. CHINA'S UNFINISHED ECONOMIC REVOLUTION (Brookings Institution Press, 1998).

${ }^{56}$ European Chamber, Shanghai Position Paper, (2014-2015), available at http://www.ccilc.pt/sites/default/files/shanghai_position_paper_2014_ 2015english_version_1_1.pdf, (last visited on Mar. 21, 2015).

57 Ming WANG, CHINAS FINANCIAL MARKETS: IsSUES AND OPPORTUNiTIES 33-34 (Routledge, 2014). 
part of the regulatory authorities coupled with rampant corruption in the Chinese capital markets lead to volatility in the securities markets making Chinese capital markets risky.58 While China has external corporate governance norms, the inability of the same to work with internal corporate governance laws in China impacts capital markets. This can be seen in the Takeover Code that only provides for a mechanism of corporate governance that must be applied when other procedures fail..$^{59}$ This creates a dichotomy in the legal structure as it takes away the importance of corporate governance norms that must be followed while simultaneously honouring the Takeover Code. ${ }^{60}$

Further, despite the presence of a comprehensive set of rules, there is a lacuna in law that continues to remain ambiguous in the absence of judicial interpretation as the governmental policies are honoured at the cost of the evolution of law in China. This is best exhibited in China's insider trading law. While the law clearly specifies what insider trading is and who can be held guilty for the same, it fails to address the liability of those who were a part of the listed organization and quit thereafter to leak information at the time of such trading. ${ }^{61}$

Another problem of capital markets in China exists in the lack of remedies to compensate investors. While certain activities and transactions are prohibited, the law does not provide grievance redressal mechanisms to compensate investors for the laxity of the complex regulatory mechanism. ${ }^{62}$

58 Yang, J., Chi, J. and Young, M., A review of corporate governance in China, 25 ASIA PAC ECON. LIT. 15-28 (2011).

${ }^{59}$ Hui, Supra note 16 at 175.

60 Pauline O'Sullivan, Governance by Exit: An Analysis of the Market for Corporate Control, in CORPORATE GOVERNANCE: ECONOMIC AND FINANCIAL ISSUES, 122-123 (Oxford University Press, 2012).

${ }^{61}$ Hui, supra note 23.

62 Yuwa, supra note 2. 


\section{Problems with Heavy Reliance on Direct Financing in China}

Secondly, most healthy capital markets around the world both in emerging and developed economies rely upon direct financing through the issuance of bonds or equities. ${ }^{63}$ China on the other hand continues to be reliant on bank loans, as direct financing especially by corporations is very limited. This is due to the control of the government and the policies that limit the growth of such corporations to ensure the survival of the state owned enterprises. ${ }^{64}$ The lack of direct financing limits the growth of capital markets in China as capital remains limited and the lack or diversity impacts the yield of Chinese capital markets.

\section{(1) Emergence of SME's}

Thirdly, China has the potential to foster Small and Medium Enterprises (SME) and channel them into the capital markets structure to ensure development. However, a dismal situation exists for SMEs in China. ${ }^{65}$ The SME board in both the Shanghai and Shenzhen Exchange are very small compared to their global counterparts and cannot accommodate the interests of the increasing SMEs in China. This in turn impacts direct financing sources of such enterprises. ${ }^{66}$ However, in 2014 China attempted to ease the funding problem of SMEs by expanding its Over the Counter (OTC) market, which was established in 2007. This expansion enables SMEs to enter the OTC Board to raise capital. This board was formed to help non-public firms raise capital and

63 Tatiana Didier and Sergio L. Schmukler, The Financing and Growth of Firms in China and India: Evidence from Capital Markets, (Dec. 7, 2012) http://blogs.worldbank.org/allaboutfinance/files/allaboutfinance/the_fi nancing_and_growth_of_firms_in_china_and_india_-

_evidence_from_capital_markets.pdf.

64 Qi, Bin, China Capital Markets Development Report : China Securities Regulation

Commission, available

at

https:/ / openknowledge.worldbank.org/handle/10986/12643,(last visited on Mar. 17, 2015).

$65 \mathrm{Id}$.

${ }^{66}$ Hongbo Duan, Xiaojie Han and Hongbo Yang, An Analysis of Causes for SMEs Financing Difficulty, 4(6) INT. J. BUS. \& MANAGEMENT, 73-74 (2009). 
allow investors to trade equities in the said market. ${ }^{67}$ Yet, the OTC market needs development to foster growth despite being a great first step towards development of SMEs in China. 68

\section{(ii) Limited Array of Traded Products}

Fourthly, the limited span of products traded on Chinese stock markets poses yet another challenge for the capital markets. Innovative products such as financial derivatives have a limited scope in China, with stock markets focusing primarily on shares and bond trading. ${ }^{69}$ This occurs due to weaknesses in the system of trading in China. In the absence of a market maker system, Chinese exchanges do not support securities borrowing and lending or intra-day trading, limiting diversification of products. ${ }^{70}$ Moreover, short selling procedures were absent in China for a long time while compared to other emerging capital markets such as in India and were only introduced by the Hong Kong - Shanghai Connect after amendments were made and became applicable on March, 2015.71

\section{(iii) Discrepancy in the Bonds Market}

Another challenge faced by Chinese capital markets, is the discrepancy between the government and corporate bonds market. China relies heavily on government bonds, leaving corporate

${ }^{67}$ Roger $\mathrm{Yu} \mathrm{Du}$, China expands its OTC market allowing SMEs to raise capital, (Jan. 3, 2014), http://globalriskinsights.com/2014/01/china-expands-itsotc-market-allowing-smes-to-raise-capital/.

68 China In a changing Global Environment, OECD Report, (Mar., 2015), available at:

http:/ / www.oecd.org/china/china-in-a-changing-globalenvironment_EN.pdf.

${ }^{69}$ Fabella, Raul and Madhur, Srinivasa, Bond Market Development in East Asia: Issues and Challenges, 1-13 (Asian Development Bank, ERD Working Paper No. 35, 2003).

70 Rosen and Wang, supra note 45.

${ }^{71}$ Lissa Jucca, Shanghai-Hongkong Stock connect to allow short-term selling from March, REUTERS, (Feb. 23, 2015), http:/ / www.reuters.com/article/2015/02/23/china-hongkong-connectidUSL4N0VX0ET20150223. 
bonds to form a minority in the bond market in China. ${ }^{72}$ Corporate bonds in China are composed only of corporate bonds from listed companies, convertible bonds and short term commercial papers. ${ }^{73}$ This is limited when compared to the options available in other mature capital markets.

\section{(iv) Efficiency Issues with Respect to the Exchanges}

Lastly, despite having a centralized registration procedure both the exchanges of China operate separately making it tougher for investors, who are forced to open different trading accounts with each stock exchange. This decreases the efficiency of Chinese capital markets and inhibits any inter exchange and inter market products from being introduced into the capital markets structure. A similar efficiency problem extends to the bond market due to its fragmented structure. ${ }^{74}$

\section{Potential of the Chinese Capital Markets}

There is no doubt that emerging economies with the size of that of China have great potential upon proper appreciation and evolution. China with its national economic size and power amongst emerging global economies is a leader due to the national saving potential of its people. The Government's recent attempts to increase savings by providing social security to people by 2030 are said to be the biggest driver of growth in capital markets. ${ }^{75}$ This will boost the creation of a pension funds market in China, which has previously not been as strong and has the potential of boosting capital markets in China manifestly, provided it is accompanied by

72 Franklin Allen, Jun “QJ" Qian, et. al. , A Review of China's Financial System and Initiatives for the Future, in CHINA'S EMERGING FINANCIAL MARKETS (The Milken Institute Series on Financial Innovation and Economic Growth, 2009).

73 OECD, China in the World Economy: The Domestic Policy Challenges, OECD, available at http://www.oecd.org/daf/fin/insurance/2075272.pdf (last visited on Mar. 18, 2015).

74 Rosen and Wang, supra note 45.

75 Ashley Kindergan, Chinese Capital Markets: A 98 Trillion Opportunity, THE FINANCIALIST, (Jul. 22, 2014), https://www.thefinancialist.com/Chinesecapital-markets-a-98-trillion-opportunity/. 
implementation of regulations. ${ }^{76}$ Further, the government's scheme of 'mixed ownership' which was announced recently could further attract foreign investors to China. The government raising the ownership limit of foreign companies from twenty to thirty percent truly shows China's commitment to private investment. ${ }^{77}$

\section{Potential of Growth via Securities Market}

In 2014, China drew attention by closing big deals both nationally and internationally in the global debt market with Chinese banks raising capital. While this paper has focused more centrally on the securities market in China, it is paramount to recognize the role of indirect financing in the Chinese capital markets. Bank loans, including foreign exchange loans form the majority along with the bond market, leaving a mere meager contribution to that of the equity markets in China. ${ }^{78}$

The poor development of type A shares in China vis-à-vis its GDP elucidates that such poor performance is only due to the unsatisfactory regulations and the lacunae in implementation of the present legal framework. Investor ignorance forms another key to this disappointing performance. ${ }^{79}$ In the future, China has the potential to raise capital through type A shares, provided the government systems are transparent and regulatory framework in the country is fine-tuned. The inclusion of type A shares by the MSCI Index is limited to those domiciled in China. ${ }^{80}$ The increasing

76 Niels Philipsen and Guangdong XU, The Role OF LAW AND REGULATION IN SUSTAINING FINANCIAL MARKETS 250-53 (Routledge, 2015). $77 \mathrm{Id}$.

78 GAO JIAN, ISSUES AND PROBLEMS OF CHINA'S DEBT EQUiTY MARKETS (2013).

79 NicolaAs Groenewold, The ChInese StOCK MARKeT: EFFICIENCY, PRedictability, AND Profitability 201-04 (Elgar Publishing Limited, 2004).

${ }^{80}$ Qi Wang and Chin-Ping Chia, China A-Shares: Too Big to Ignore, MSCI RESEARCH INSIGHT, (Sep.

2014), https://www.msci.com/resources/research/articles/2014/Research_Insi ght_China_AShares_Too_Big_to_Ignore_September_2014.pdf (last visited on Sep. 24, 2009). 
number of Chinese companies being listed on international stock markets such as the NYSE has led to including Chinese American Depository Receipts (ADR) to MSCI'S China Index. ${ }^{81}$ This in turn could be a golden invitation to investors globally especially in the USA to explore Chinese equity markets.

Chinese bond markets while compared to Type A shares have seen sunnier days and this form of direct financing is encouraged both internationally and in China. Overcoming the challenges of market segmentation caused by political reasons such as the categorization of the bond market into three, primarily the Shanghai and Shenzhen Exchanges by the CSRC regulations, the PBOC'S bank market and lastly corporate banks leave the bond market inconsistent and can often cause competition and conflicts within the three for raising capital. Evolution of an integrated bond market with one regulator could enable China harness greater capital in the future. ${ }^{82}$

\section{Potential Investment Attractions in China}

Secondly, investment in China has great potential due to the size of this emerging economy and its technological advances. However, it is essential to recognize that the risks of investment in emerging economies is much greater than in developed economies such as the United States of America. While investment can yield high gain, the probability of non-payment, volatility of the markets, exchange controls and trade deficit continue to plague China. ${ }^{83}$ The absence

81 Joseph Tang, China's New Normal: Exhilaration in Deceleration, (Jan. 9, 2015), http:/ / www.blog.invesco.us.com/chinas-new-normal-exhilarationdeceleration. (The MSCI China Index is an unmanaged index considered representative of Chinese Stocks. The MSCI World Index is an unmanaged index considered representative of stocks of developed countries. The MSCI Emerging Markets Index is an unmanaged index considered representative of stocks of developing countries. An investment cannot be made an index).

82 Chen Xindong, Chinas Capital Markets; Untapped Potential, Eurobiz, (Jun. 10, 2013), http://www.eurobiz.com.cn/chinas-capital-markets-untappedpotential/.

83 Burton G. Malkiel, The Efficiency of the Chinese Stock Markets: Some Unfinished Business on the Road to Economic Transformation (Princeton 
of strong regulations to back the securities market in China has been addressed in the previous sections and addressing this key issue could enable China to draw investment from global companies and states. ${ }^{84}$

\section{Emergence of the Hong Kong - Shanghai Stock Connection and its Potential}

The recent launch of the Hong Kong- Shanghai stock connection promises to improve capital markets both in China and Hong Kong. While it has been argued that Hong Kong exchanges prosper due to their geographic proximity with China and China's capital markets improving would drive capital out from Honk Kong, this scheme is an attempt from both countries to improve cross border capital market transactions. ${ }^{85}$ The Stock connect enables stocks that are listed on the Shenzhen Exchange to be traded between the two states and is followed with a set of new rules allowing mainland investors in China to invest in Hong Kong's exchange traded funds. This also allows Hong Kong companies that have joint ventures with China to access the capital markets of the mainland. ${ }^{86}$ The message sent out by this undertaking is clear and announces China's opening of doors to global exchange and foreign exchange. ${ }^{87}$ Typical of China, this scheme is not huge but forms a baby step towards the opening of Chinese stock markets. Allowing

University, CEPS Working Paper No. 154, December 2007).

${ }^{84}$ Eddie Chow, Capital Market Reforms in China: Gaining Momentum, (July 17, 2014), available at http:/ / mobius.blog.franklintempleton.com/2014/07/17/capital-marketsreform-china-gaining-momentum/ (last visited on Mar. 19, 2015).

85 Thomson Reuters, The through train: stock connect's impact and future, (Dec., 2014),

http:/ / share.thomsonreuters.com/assets/forms/shanghai-hk-stockconnect-1008885.pdf.

86 Kana Nishizwana, Fion Li \& Billy Chan, China Opens Door to $\$ 97$ Billion of Fund Sales Via Hong Kong, BLOOMBERG Business (May, 2015), http:/ / www.bloomberg.com/news/articles/2015-05-22/china-hongkong-to-start-cross-border-mutual-fund-sales-july-1.

87 William Barkshire, Chinese Financial Markets set for landmark 2015, (Dec. 25, 2014), http://asia.nikkei.com/print/article/67155. 
the symbiotic free trading between Hong Kong and China enables a possible expansion of investor opportunities in China. Further, the caps on both QFII and QDII have been increased to complement the intentions of this scheme. 88

\section{Conclusion}

The author concludes by elucidating the multiple challenges faced by Chinese capital markets primarily due to the state's intervention and long history of governmental control. The facets of legislation, adjudication and execution can be both directly and indirectly traced to the government thereby breaking any checks and balances in the capital markets structure. This in turn has led to loss of faith in the capital markets in China, as investors most often find their investments being channeled based upon the Government's decisions. This has led to limited growth in the markets via foreign investors who continue to remain apprehensive about the volatility of Chinese capital markets. Yet, despite the obstacles in the path, the author argues for a great potential in the rise of capital markets in China and has put forth arguments for the same that have been summarized below.

With the introduction of yet another securities regulation, Chinese capital markets can hope to see a brighter future. The prospective changes that range from the introduction of alternate modes of payment, information disclosure and more transparent government approvals will open up a spectrum of opportunities for investment in the capital markets especially the securities market in China to both national and foreign investors 89 .

While China has been introducing consecutive changes in its existing legal framework and forming new regulations, the key to any change lies in its implementation. Implementation poses a great obstacle in China due to the governmental authority. ${ }^{90}$ Yet the

88 Y.Nancy Ni, China's Capital Flow Regulations: The Qualified Foreign Institutional Investor And The Qualified Domestic Institutional Investor Programs, 28 REV. BANKING \& FIN. L. 299, 314 (2009).

89 Feinerman, James V., "New Hope for Corporate Governance in China?" (2007), Georgetown Law Faculty Publications and Other Works. Paper 589.

90 ZHEN, supra note 46. 
future holds the potential of cross border transactions taking place in the Chinese capital markets. Such transactions could help the state and governmental sector while giving the nationals an incentive to invest the state's shares. Given the importance of state enterprises in China any investment to the capital markets for state shares could prove to be path breaking. ${ }^{91}$

State organizations will get capital and the possibility of increased production due to capital raised can also provide employment opportunities to China's large population while increasing the efficiency of such organizations as foreign investors would remain keen to see growth. ${ }^{92}$ Investing in state securities enables not just growth of state run organizations, but also boosts national infrastructure making China a land of high risks and higher yield. Following the western model, securitization laws in China have attempted to develop securities markets further and set the ball rolling for China, but the development of the bond market and limited availability of financial derivatives continue to plague China. ${ }^{93}$

In conclusion, Chinese capital markets can reach their peak by implanting effective methods of maximizing both direct and indirect financing. Given the high volume of production in China and its population, a transparent and a well defined regulatory framework that does not undergo changes as often as we have witnessed could enable China to become a truly modern capital markets state. However, the challenges of the cultural and economic ethos of China impede the successful implementation of positive reforms that have been undertaken. Curbing the corruption embedded in the political system would be the definitive solution for Chinese capital markets along with giving education to investors and training legal and account audit staff.

${ }^{91}$ Nicholas J. Faleris, Cross-Border Securitized Transactions: The Missing Link in Establishing a Viable Chinese Securitization Market, 26 NW. J. INT'L L. \& Bus., 201-203 (2005).

92 Id.

93 Ong, Allan Verman Yap, How the Implementation of Securitization in China Can Avoid the Problems that Caused the Financial Crisis that Arose in the United States, COLUM J. ASIAN L. (2010). 
Hence, the potential of China has the worlds' attention, but the future remains uncertain in reality. 